\title{
Contents to Volume 14 (2018)
}

\author{
Editorial 1
}

List of Abbreviations 2

\section{RESPONSES TO CONFLICT IN EARLY CHRISTIANITY}

Romani principes aduersum nos prouocantur: Augustine of Hippo's Epistula 87 to Emeritus of Caesarea 7

Geoffrey D. Dunn

A Christian Response to the Conflicting Relationship between Slave and Master in a Christian Household: Investigating Paul's Response to the Conflict between the Economic Relationship and the Christian

Brotherhood's Relationship in the Letter to Philemon $\quad 25$ Hon Ho Ip

The Eusebian and Meletian Roots of John Chrysostom's Trinitarian Theology 37

Pak-Wah Lai

A Freedom beyond Conflict: The Logic of Internal Conflict and the Free Will in Maximus the Confessor 63

Basil Lourié

Imitating the Devil: Cyprian on Jealousy and Envy 75 Edwina Murphy

Addressing Conflict in the Fifth Century: Rome and the Wider Church 92 Bronwen Neil

The Apology of Justin Martyr and the Legatio of Athenagoras: Two

Responses to the Challenge of Being a Christian in the Second

Century 115

Mary Sheather

To Flee or not to Flee? Third Century Flight in Persecution 133 Ruth Sutcliffe

Rhetorical, Political, and Ecclesiastical Perspectives of Augustine's and Julian of Eclanum's Theological Response in the Pelagian Controversy $\quad 161$ Nozomu Yamada 
RELIGION, PHILOLOGY, AND SLAVIC CULTURES: SLAVONIC APOCRYPHA

Introduction 195

Ljubica Jovanovic

Slavonic Translation of the Apocryphal Questions of Bartholomew 197 Martina Chroma

Apocryphal Tradition and Slavonic Pilgrimage Literature 206

Marcello Garzaniti

The Protoevangelium of James and Its Reception in the Caucasus: Status

Quaestionis 223

Cornelia B. Horn

The Reception of "Slavonic Apocrypha" 239

Ljubica Jovanovic

Rewritten Bible in the "Museum" Slavonic Translation of the Song of

Songs 257

Basil Lourié

Slavonic Apocrypha: New Discoveries, New Perusals The Cases of the

Dispute between Our Lord Jesus Christ and the Antichrist and the Story about BeautifulJoseph 273

Anissava Miltenova

How to Study the Slavic Apocrypha in the 21st Century? Case Study: The Use of Moses and the Plagues Narratives in the Slavic Cultures $\quad 289$

Sladjana Mirkovic

The Dream of King Jehoash: A Textual Analysis 298

Keiko Mitani

Slavonic Apocrypha: the Main Problems with Their Textual History (a Philological Perspective) 318

Liudmila Navtanovich

The Representation of Literary Motifs in the Visual Arts (in Connection with the Magic Belts of Job and His Daughters) 328

Lybov Osinkina

The Debate on Medieval Western Christian Dualism through the Prism of Slavonic Pseudepigrapha 334

Yuri Stoyanov

Neither Pseudo-Athanasius nor Palaea: Historia de Melchisedech as a Part of the Slavonic Abraham's Cycle $35^{1}$

Maria Vitkovskaya and Vadim Wittkowsky 


\section{ARTICLES}

An Ostracon Related to Archangel Michael's Cult in Upper Egypt 369 Hind Salah El-Din Somida Awad

Neilos Kabasilas's Rule of Theology and the Distinction between the Light and Warmth of Fire in Neilos Kabasilas and Gregory Palamas 373

Dmitry Biriukov

Affirming Divine Providence and Limiting the Powers of Saints: the Byzantine Debate about the Term of Life (6th-11th Centuries) 392 Dirk Krausmüller

Seven Sessions or Just a Letter? Observations on the Structure of the Disputations between Elias, Metropolitan of Nisibis, and the Vizier Abū l-Qāsimal-Maghribī 434 Nikolai N. Seleznyov

Philoponus on the Nature of the Heavens and the Movement of Elements in the Against Aristotle on the Eternity of the World 446 Maria Varlamova

\section{NOTES}

The Fixed Easter Cycle in the Ethiopian Church $\quad 463$ Ekaterina V. Gusarova

Eunomius and Gregory of Nyssa on the Principle of "the More and the Less" and Its Application to the Category of Substance 467

Dmitry Biriukov

\section{REVIEW ARTICLE}

The Cambridge Intellectual History of Byzantium, eds. Anthony Kaldellis, Niketas Siniossoglou, Cambridge, $2017 \quad 475$ Dmitry Chernoglazov, Grigory Benevich, Arkadi Choufrine, Oksana Goncharko and Timur Schukin

BOOK REVIEWS

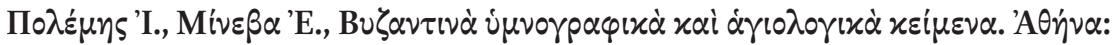

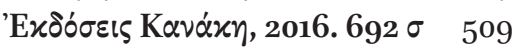

Dmitry Afinogenov 
Н.Н. Селезнев, Книга собеседований Илии, митрополита Нисивина, с везиром Абӯ-л-Ка̄симом ал-Хусайном ибн 'Алй ал-Магрибй и Послание митрополита Илии везиру Абӯ-л-Ка̄симу, Национальный Исследовательский Университет Высшая Школа Экономики, Институт Классического Востока и Античности, Москва: Грифон; N.N. Seleznyov (ed.), The Book of Sessions by Elia, the Metropolitan of Nisibis $<$ which he had > with the vizier Abū l-Qāsim al-Ḥusayn ibn 'Alī al-Mag̉ribī and the Letter of the Metropolitan Elia to the vizier Abū l-Qāsim, National Research University «Higher School of Economics», Institute for Oriental and Classical Studies, Moscow: Grifon $\quad 512$ Dmitry Fedorovich Bumazhnov Арутюн С. Жамкочян, Житие св. Григория просветителя Армении по арабской синайской рукописи 455, Ереван: «Гитутюн», 2016, p. 320; Haroutiun S. Jamkochian, The Life of St. Gregory the Illuminator of Armenia in Ms. Sin. Ar. 455, Yerevan: "Gitutyun," 2016, p. 320 (in Russian, with Arabic edition, Arabic facsimile, and summaries in Armenian and English) 517 Alexander Treiger 